\title{
Thick Activated Carbon Sheet Electrode and Hydrophobic Organic Matter Improve the Performance of Microbial Fuel Cell
}

\author{
Naoki Hayashi, Dang Trang Nguyen, and Kozo Taguchi
}

\begin{abstract}
Recently, there are a lot of environmental problems all over the world. Mass-consumption of fossil fuels contribute to depletion of them, emission of large amount of carbon dioxide, and global warming. However, fossil fuels are used everywhere and they are essential for modern life to get energy. A microbial fuel cell (MFC) is one of the new energy resources. This study focused on activated carbon sheet that has property of absorbing organic matter and large surface area. In this study, the experiment was conducted in eight conditions that were combined organic matter, kind of electrode and thickness of the electrode. Biofilm was built on two kinds of anodes that were made of carbon sheet and activated carbon sheet by using glucose or malt powder. The combination of using activated carbon sheet and malt powder produced maximum current density of $220 \mu \mathrm{A} / \mathrm{cm}^{2}$.
\end{abstract}

Index Terms-Microbial fuel cell, biofilm, activated carbon, hydrophobic organic matter, baker's yeast, electrode thickness.

\section{INTRODUCTION}

It is important to reduce carbon dioxide in order to prevent global warming. Therefore, clean and renewable energy without emitting carbon dioxide is needed. Microbial fuel cell (MFC) is one of the new energy resources. MFC is a device that generate electricity by using microbes.

There are two kinds of MFC that are single chamber type and double chamber type. In single chamber type of MFC, the cathode electrode is exposed to the air. It is called aircathode MFC [1]. Double chamber MFC is divided into two chambers by a proton exchange membrane (PEM) [2]. Usually, potassium ferricyanide is used as oxidant in the cathode chamber of double chamber MFC. In this study, this double chamber MFC was used.

In double chamber MFC, electrons and protons are generated in anode chamber when the microbe decompose organic matter. The electrons travel to cathode chamber through an external circuit. The protons transport through PEM to cathode chamber. Thus, the MFC can convert chemical energy to electric energy (Fig. 1).

In MFC, a mediator was usually used in order to transfer electrons from microbes to the anode electrode [3]. Methylene blue, humic acids and resazurin were used as mediators [4]. Mediators play an important role in this way. However, most mediators have toxic property. Therefore, when the device is operated using mediators, harmful effect might happen. [5] Then, there is a method that uses biofilm

Manuscript received November 13, 2018; revised January 4, 2018.

The authors are with the Department of Science and Engineering, Ritsumeikan University, Shiga, Japan (e-mail: taguchi@se.ritsumei.ac.jp). instead of adding mediator to the anode chamber. Biofilm is a structured community of surface-associated microbial cells [6], [7]. Biofilm is studied in various fields such as environment, industry, medicine and so on. [8]. In medical field, biofilm is built on medical device and cause various infection. Therefore, there are issues that developing preventative of building biofilm [9]. It does not have only bad aspects but also have good aspects. When biofilm is built in the anode electrode of MFC, electricity is generated without mediator. The electrons that are emitted by microbe's decomposition of organic matter are directly transferred to the anode electrode. Therefore, using biofilm in anode lead to high electricity generation without the need of mediator. It is important to select electrode material when biofilm is built on the electrode.

Metal materials are usually used as the electrode in batteries. Pt is commonly used as the electrode in fuel cells. However, Pt is expensive material. In the MFC, carbonbased materials are commonly used as the electrodes. They are non-metal and has high conductivity. Activated carbon is one of the carbon materials and it has good properties of hydrophilic, abundant pores and large internal surface area [10]. In addition, when biofilm is built on activated carbon material, it enhances biofilm growth [11].

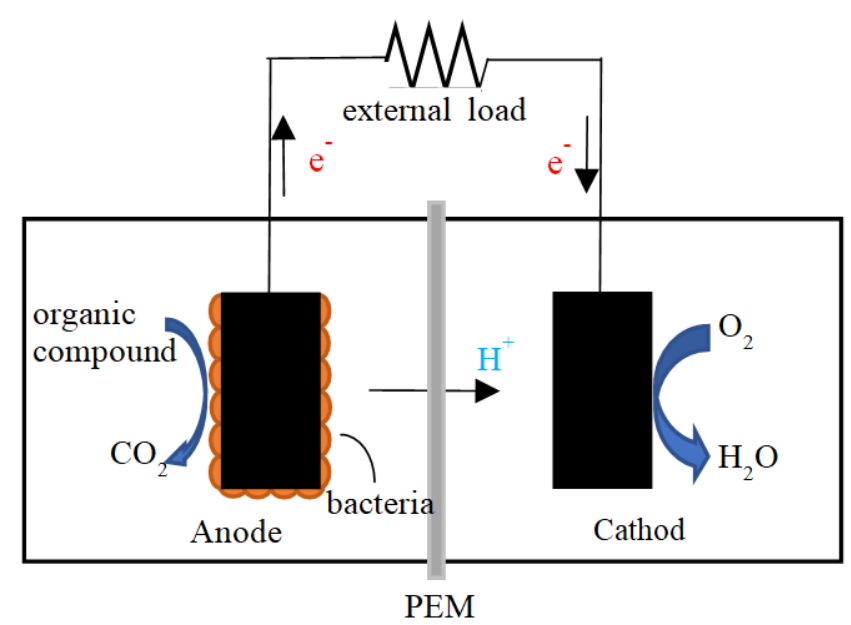

Fig. 1. Operating principle of MFC.

Moreover, microbe and organic matter are important elements for MFC operation. Saccharomyces Cerevisiae is a common baker's yeast that generate electrons by decomposing organic matter in MFC [12]. The baker's yeast is able to decompose glucose that is commonly used as organic matter in MFC. Yeast bacteria and glucose are used in food industry. In addition, baker's yeast decompose malt 
powder that is one of the organic matter. Malt powder is hydrophobic organic matter and include starch and amylase that converts starch to glucose. Thus, in this study, we focused on hydrophobic property of malt powder and adsorption property of activated carbon. We assumed that when activated carbon sheet and malt powder were used, biofilm quality and electricity generation were promoted.

\section{MAterial AND Methode}

\section{A Construction of the $M F C$}

The MFC was constructed with an anode chamber, a PEM, and a cathode chamber as shown in Fig. 2. Each chamber was made by silicon. The volume of anode chamber was $3.5 \mathrm{~cm} \times 3.5 \mathrm{~cm} \times 0.5 \mathrm{~cm}$ and cathode chamber was $3.5 \mathrm{~cm} \times 3.5 \mathrm{~cm} \times 0.3 \mathrm{~cm}$. Anode and cathode electrode materials were carbon sheet or activated carbon sheet. Each electrode size was $1 \mathrm{~cm} \times 1 \mathrm{~cm}$. Carbon sheet or activated carbon sheet, that was built biofilm, was used as the anode electrode.

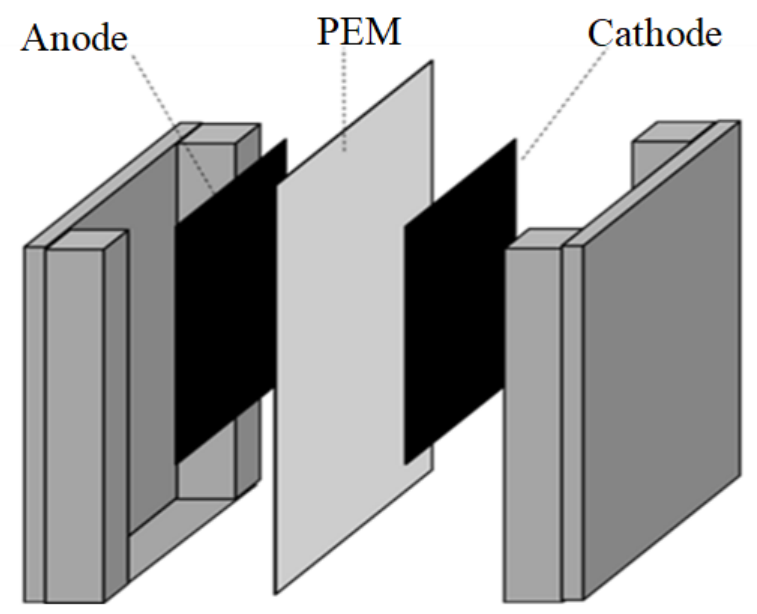

Fig. 2. Construction of the MFC.

\section{B Biofilm}

In this study, biofilm was built on activated carbon sheet and carbon sheet using baker's yeast. Furthermore, when yeast was cultured, glucose or malt powder were used as organic matter. The biofilm was built as follows. Firstly, solution of $70 \mathrm{~g} / \mathrm{L}$ baker's yeast was made. Secondly, solution of $50 \mathrm{~mL}$ pure water, $0.5 \mathrm{~mL}$ "Hana koujo" (nitrogen: $5 \%$, water-soluble phosphorus: $10 \%$, watersoluble potassium: $5 \%$, water-soluble magnesium: $0.08 \%$, water-soluble manganese: $0.004 \%$, water-soluble boron: $0.016 \%), 1 \mathrm{~g}$ malt powder or glucose, $1 \mathrm{~g}$ additive-free bouillon, the $0.3 \mathrm{~mL}$ was made. Then the two solutions were mixed together. Carbon sheet or activated carbon sheet were put into a cup contained $50 \mathrm{ml}$ of the final solution [13]. Finally, the cup was put in an incubator at 30 degrees.

\section{$C$ Operation of the $M F C$}

Anode chamber was fed with $5 \mathrm{ml}$ medium that consisted of $1 \mathrm{~mL}$ "Hana koujo", $0.1 \mathrm{~g}$ malt powder and $4 \mathrm{ml}$ pure water. 2 types of carbon sheet (thickness: $0.2 \mathrm{~mm} 0.6 \mathrm{~mm}$ ) and activated carbon sheet (thickness: $0.2 \mathrm{~mm} 0.6 \mathrm{~mm}$ ), that were formed biofilm, were used as the anode electrode.
Biofilm of baker's yeast was built in two ways that added glucose or malt powder as organic compound. Cathode chamber was fed with $5 \mathrm{ml}$ of $300 \mathrm{mM}$ potassium ferricyanide solution, and activated carbon sheet and carbon sheet was used cathode electrode [14]. The MFC was operated in batch mode. Voltage was measured by open circuit and then the device was connected to external resistor of $10 \mathrm{k} \Omega$ and $1 \mathrm{k} \Omega$ [15]. Then current density was calculated using Ohm Law .

\section{$D$ Condition of the Experiment.}

In this study, the experiment was conducted in eight conditions (Table I). Thickness of the electrodes was also a variable factor in our experiment. Thickness of the electrode was $0.2 \mathrm{~mm}$ and $0.6 \mathrm{~mm}$. The anode and cathode electrodes were used same materials. In addition, same organic matter was used for culturing the microbes and measuring voltage.

TABLE I. CONDITION OF THE EXPERIMENT

\begin{tabular}{|l|c|l|}
\hline \multicolumn{1}{|c|}{ Electrode } & Thickness (mm) & Organic matter \\
\hline carbon sheet & 0.2 & glucose \\
\hline activated carbon sheet & 0.2 & glucose \\
\hline carbon sheet & 0.2 & malt powder \\
\hline activated carbon sheet & 0.2 & malt powder \\
\hline carbon sheet & 0.6 & glucose \\
\hline activated carbon sheet & 0.6 & glucose \\
\hline carbon sheet & 0.6 & malt powder \\
\hline activated carbon sheet & 0.6 & malt powder \\
\hline
\end{tabular}

\section{EXPERIMENTAL RESULT}

Baker's yeast was cultured using glucose for three days and biofilm was built on $0.2 \mathrm{~mm}$ thickness activated carbon sheet and carbon sheet in the $3^{\text {th }}$ day. Experimental result was shown in Fig. 3. When biofilm was formed on the 0.2 $\mathrm{mm}$ carbon sheet (CS) and using glucose, OCV was about $0.4 \mathrm{~V}$ that is the higher value than that of the activated carbon sheet (AC). However, when external resistance was connected, the voltage was decreased significantly. Especially, the voltage, that was measured over $1 \mathrm{k} \Omega$, was about $2 \mathrm{mV}$. It indicates that carbon sheet electrode generates hardly electricity. That is because when carbon sheet was used in MFC, the internal resistance was high.

When $0.2 \mathrm{~mm}$ activated carbon sheet and glucose was used, OCV was about $0.2 \mathrm{~V}$ that is about a half value of using carbon sheet. However, unlike carbon sheet, the voltage across $10 \mathrm{k} \Omega$ resistor was about $0.18 \mathrm{~V}$ that was similar value to the OCV. Moreover, when external resistor of $1 \mathrm{k} \Omega$ was connected, the voltage was about $50 \mathrm{mV}$ that is higher value than using carbon sheet.

Next, the experiment was conducted changing glucose to malt powder cultured time was 3 days (Fig. 4). The graph of each voltage that was measured using malt powder was almost similar to the graph using glucose (Fig. 3). When carbon sheet and malt powder were used, voltage across 1 
$\mathrm{k} \Omega$ resistor was about $2 \mathrm{mV}$ that was lower value than activated carbon sheet.

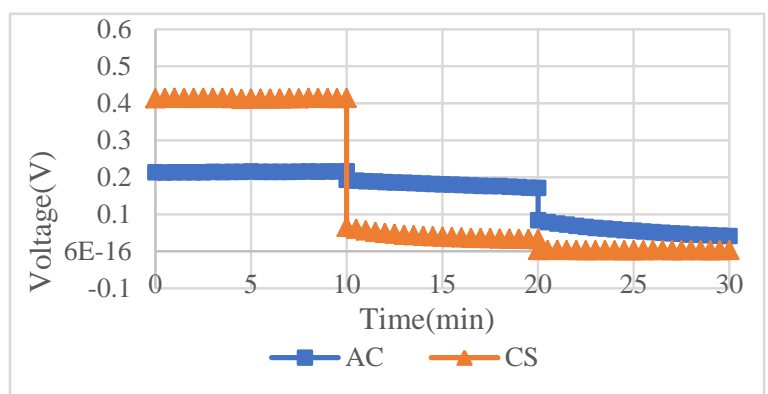

Fig. 3. Experimental result of using $0.2 \mathrm{~mm}$ thickness electrode and glucose in the 3th day. (AC: activated carbon sheet, CS: carbon sheet).

OCV and voltage across $10 \mathrm{k} \Omega$ resistor that were measured using activated carbon and malt powder were about $0.25 \mathrm{~V}$ and $0.2 \mathrm{~V}$. Compared with using glucose, that were higher value. Voltage across $1 \mathrm{k} \Omega$ resistor was almost the same as the case using glucose.

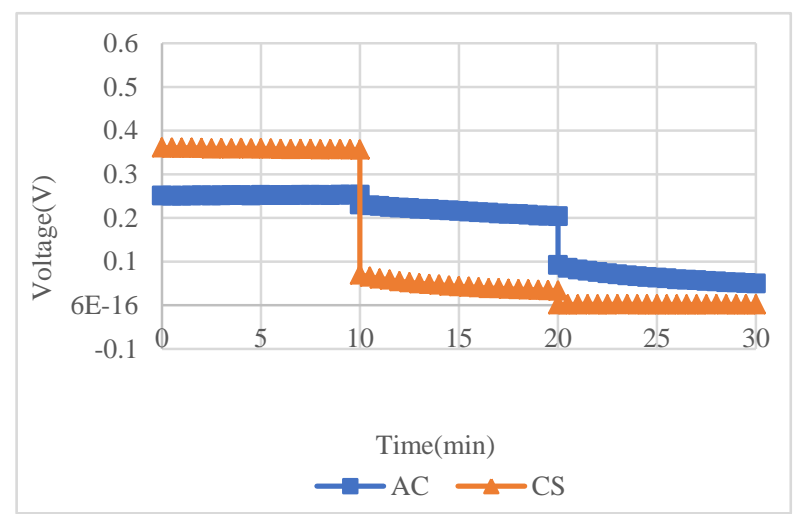

Fig. 4. Experimental result of using $0.2 \mathrm{~mm}$ thickness electrodes and malt powder in the 3 th day.

Fig. 5 and Fig. 6 shows that a daily transition of each voltage that was measured using $0.2 \mathrm{~mm}$ thickness carbon sheet and glucose or malt powder. When glucose was used, each voltage was almost constant value for three days. On the other hands, when malt powder was used, OCV was increased day after day and about $0.4 \mathrm{~V}$ that was similar value to using glucose at the $3^{\text {rd }}$ day. The voltage across 10 $\mathrm{k} \Omega$ and $1 \mathrm{k} \Omega$ resistor were same result as using glucose for all three days.

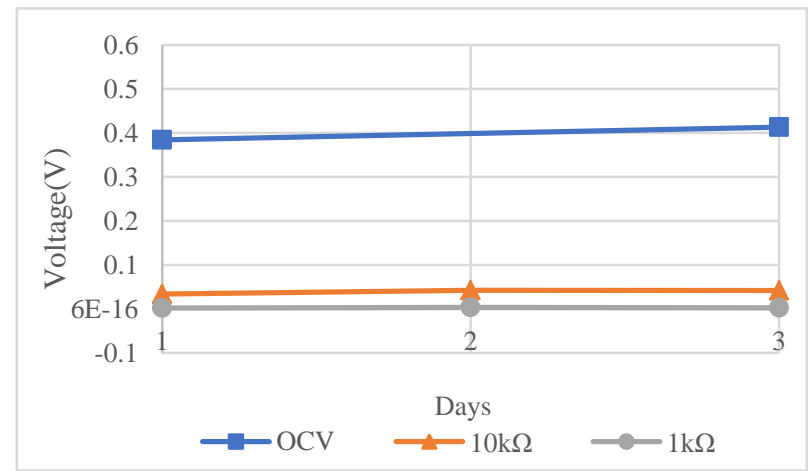

Fig. 5. A daily transition of each voltage that was measured using $0.2 \mathrm{~mm}$ thickness carbon sheet and glucose.

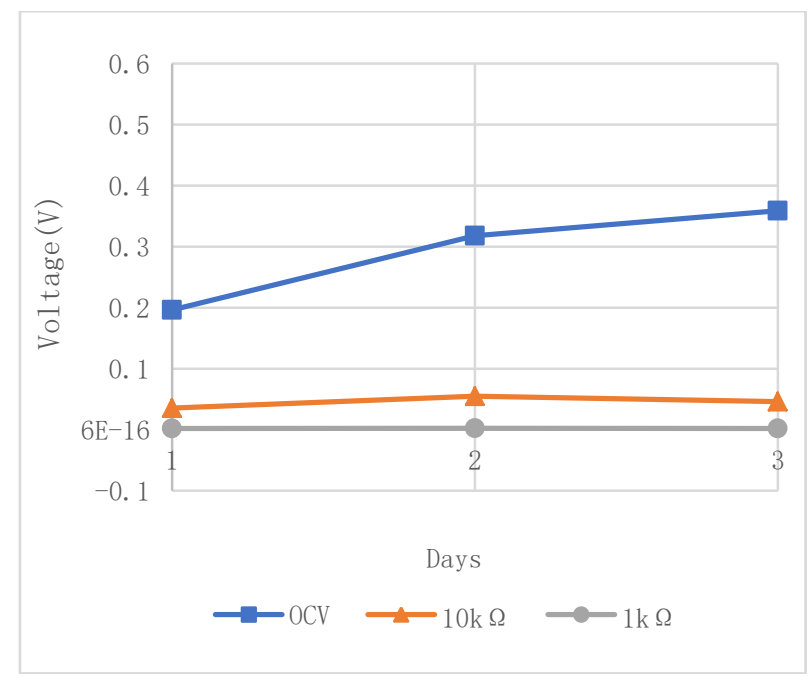

Fig. 6. A daily transition of each voltage that was measured using $0.2 \mathrm{~mm}$ thickness carbon sheet and malt powder.

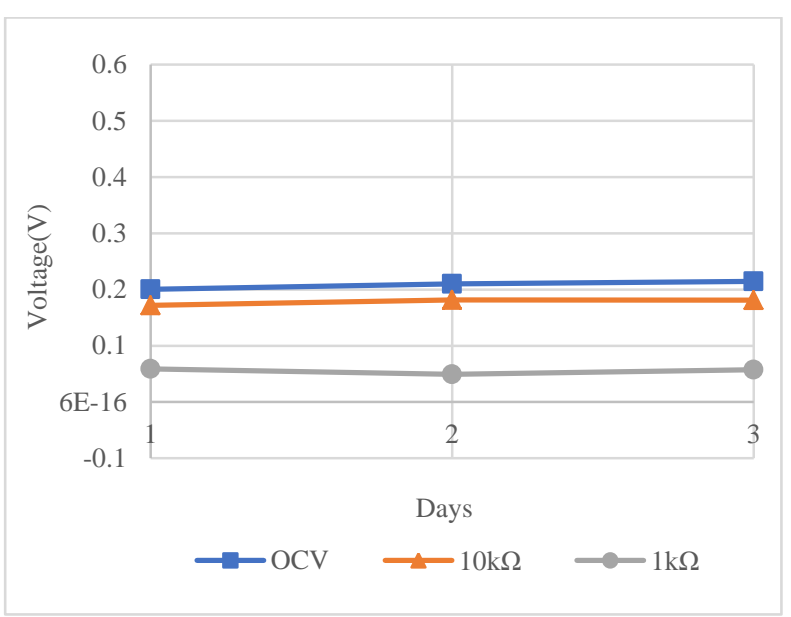

Fig. 7. A daily transition of each voltage that was measured using $0.2 \mathrm{~mm}$ thickness activated carbon sheet and glucose.

Fig. 7 and Fig. 8 show daily transition of each voltage that was measured using $0.2 \mathrm{~mm}$ thickness activated carbon sheet and glucose or malt powder. For three days, use of carbon sheet as electrode generated higher value of OCV than activated carbon sheet. However, when the device was connected to external resistor, the voltage that measure using activated carbon sheet was higher value than using carbon sheet in all the times.

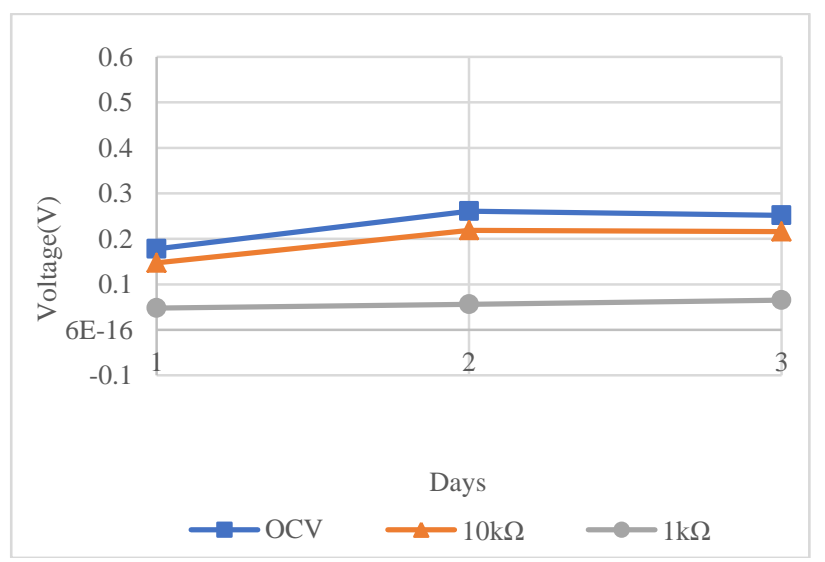

Fig. 8. A daily transition of each voltage that was measured using $0.2 \mathrm{~mm}$ thickness activated carbon sheet and malt powder.

Next, the result of the experiment, that used $0.6 \mathrm{~mm}$ 
thickness electrode, shows in following graphs (Fig. 9 and Fig. 10).

When biofilm was formed and grown by using glucose on $0.6 \mathrm{~mm}$ thickness carbon sheet, OCV was about $0.45 \mathrm{~V}$ that is higher value than using $0.6 \mathrm{~mm}$ thickness activated carbon sheet and glucose. However, when external resistor was connected to the device that electrode is $0.6 \mathrm{~mm}$ thickness carbon sheet, the voltage was decreased significantly. Especially, the voltage that was measured connecting external resistance of $1 \mathrm{k} \Omega$ was about $5 \mathrm{mV}$. It indicates that electrode of $0.6 \mathrm{~mm}$ thickness carbon sheet generates hardly electricity. That is because when carbon sheet was used in MFC, the internal resistance was high. Unlike carbon sheet, when activated carbon was used, the voltage across $10 \mathrm{k} \Omega$ resistor was similar value to OCV. In addition, the voltage across $1 \mathrm{k} \Omega$ resistor was about $0.2 \mathrm{~V}$ that was higher value than using $0.6 \mathrm{~mm}$ thickness carbon sheet.

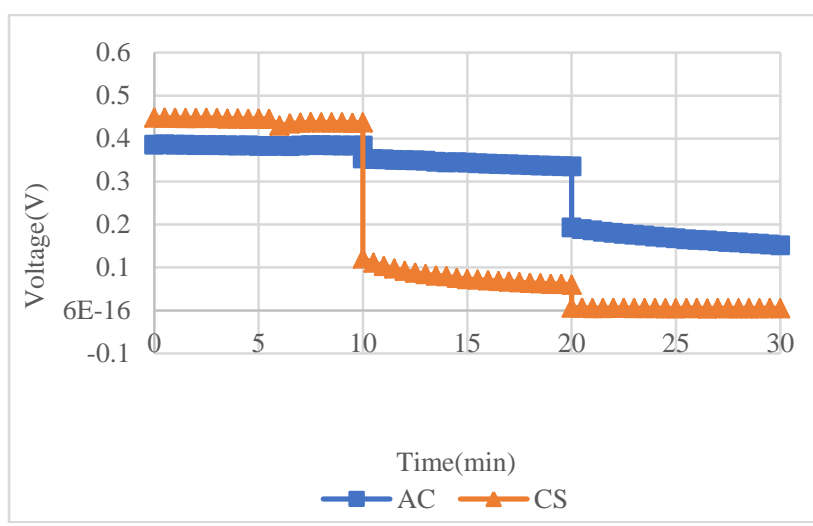

Fig. 9. Experimental result of using $0.6 \mathrm{~mm}$ thickness electrode and glucose in $15^{\text {th }}$ day.

Fig. 10 shows the result of the experiment that used $0.6 \mathrm{~mm}$ thickness electrode and malt powder in culturing yeast for nine days. Experimental result of the device that used $0.6 \mathrm{~mm}$ thickness carbon sheet and malt powder were almost the same as result of using $0.6 \mathrm{~mm}$ thickness carbon sheet and glucose. When $0.6 \mathrm{~mm}$ thickness activated carbon sheet and malt powder were used, OCV and the voltage across $10 \mathrm{k} \Omega$ and $1 \mathrm{k} \Omega$ resistor was highest value compared to the other conditions.

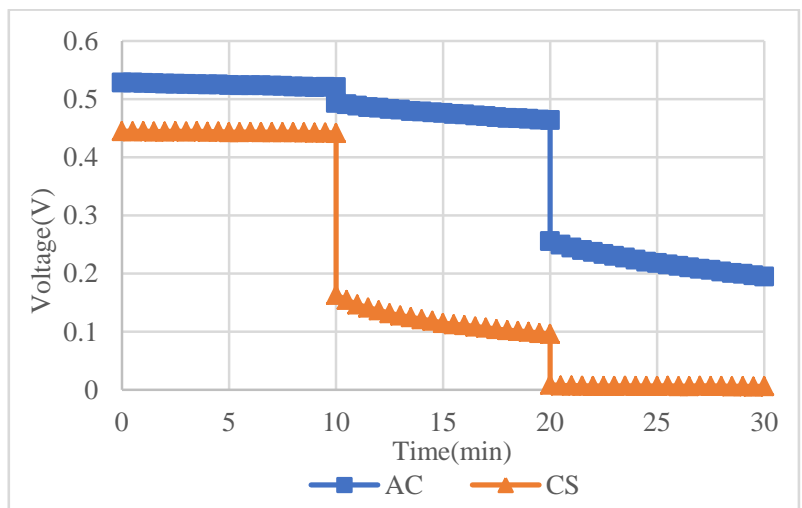

Fig. 10. Experimental result of using $0.6 \mathrm{~mm}$ thickness electrode and malt powder in the $9^{\text {th }}$ day.

Fig. 11, Fig. 12 and Fig. 13 show a daily transition of each voltage that was measured using $0.6 \mathrm{~mm}$ thickness electrode and culturing microbes for about twenty days. Fig.
11 shows the result of the experiment that used $0.6 \mathrm{~mm}$ thickness carbon sheet and malt powder and culturing for twenty days. OCV and voltage across $10 \mathrm{k} \Omega$ resistor were increased to the $9^{\text {th }}$ day. However, the voltage across $1 \mathrm{k} \Omega$ resistor was about $6 \mathrm{mV}$ all the time due to its high internal resistance.

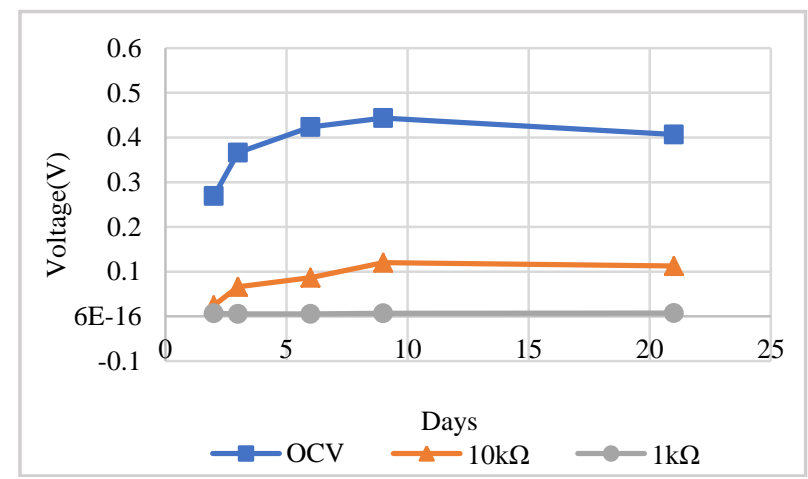

Fig. 11. A daily transition of each voltage that was measured using $0.6 \mathrm{~mm}$ thickness carbon sheet and malt powder.

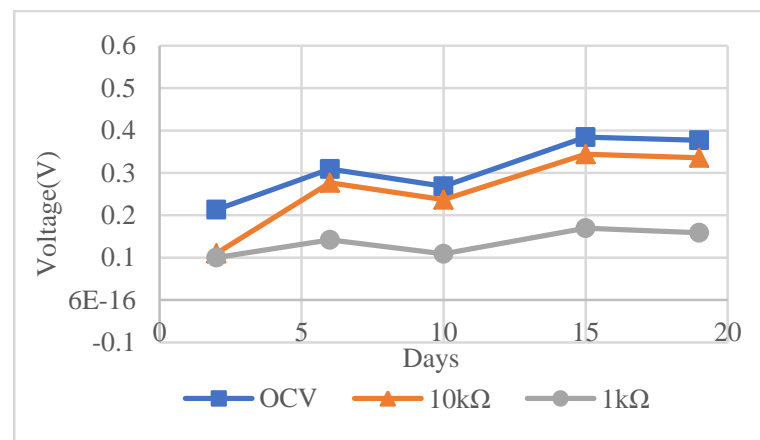

Fig. 12. A daily transition of each voltage that was measured using $0.6 \mathrm{~mm}$ thickness activated carbon sheet and glucose.

Fig. 12 shows that when the microbes were cultured in the first 15 days, voltage increases gradually. Compare Fig. 11 to Fig. 12, OCV that used $0.6 \mathrm{~mm}$ thickness carbon sheet was higher than using $0.6 \mathrm{~mm}$ thickness activated carbon sheet. However, when the device was connected to resistors, the voltage that was measured using $0.6 \mathrm{~mm}$ thickness activated carbon sheet was higher than using $0.6 \mathrm{~mm}$ thickness carbon sheet.

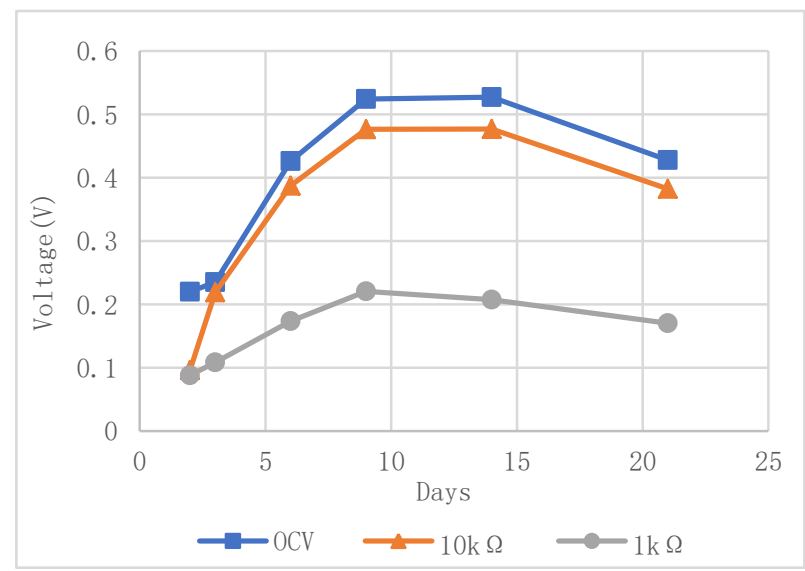

Fig. 13. A daily transition of each voltage that was measured using $0.6 \mathrm{~mm}$ thickness activated carbon sheet and malt powder.

Fig. 13 shows daily transition of each voltage value that 
was measured using $0.6 \mathrm{~mm}$ thickness activated carbon sheet and malt powder. On the first day, OCV was about 0.2 $\mathrm{V}$ and voltage across $1 \mathrm{k} \Omega$ and $10 \mathrm{k} \Omega$ were about $0.1 \mathrm{~V}$ that was almost the same value. Each voltage was increased until the $9^{\text {th }}$ day. The voltage values were almost unchanged between the $9^{\text {th }}$ day and the $14^{\text {th }}$ day and decreased from the $14^{\text {th }}$ day. Compared with other conditions, this condition, that used $0.6 \mathrm{~mm}$ thickness activated carbon sheet and malt powder, produced the highest voltage.

TABlE II. CAlculated CURRent Density

\begin{tabular}{|c|c|c|c|c|}
\hline \multirow{2}{*}{ Electrode } & \multirow{2}{*}{$\begin{array}{c}\text { Thickness } \\
\text { (mm) }\end{array}$} & \multirow{2}{*}{$\begin{array}{c}\text { Organic } \\
\text { matter }\end{array}$} & \multicolumn{2}{|c|}{$\begin{array}{c}\text { Current density } \\
\left(\mu \mathrm{A} / \mathbf{c m}^{2}\right)\end{array}$} \\
\hline & & & $10 \mathrm{k} \Omega$ & $1 \mathrm{k} \Omega$ \\
\hline $\mathrm{CS}$ & 0.2 & glucose & 4.2 & 2.3 \\
\hline $\mathrm{AC}$ & 0.2 & glucose & 18.2 & 55.2 \\
\hline CS & 0.2 & $\begin{array}{c}\text { malt } \\
\text { powder }\end{array}$ & 4.6 & 1.9 \\
\hline $\mathrm{AC}$ & 0.2 & $\begin{array}{c}\text { malt } \\
\text { powder }\end{array}$ & 21.6 & 65 \\
\hline $\mathrm{CS}$ & 0.6 & glucose & 7.9 & 5.3 \\
\hline $\mathrm{AC}$ & 0.6 & glucose & 34 & 169 \\
\hline CS & 0.6 & $\begin{array}{c}\text { malt } \\
\text { powder }\end{array}$ & 12 & 6.8 \\
\hline $\mathrm{AC}$ & 0.6 & $\begin{array}{c}\text { malt } \\
\text { powder }\end{array}$ & 48 & 220 \\
\hline
\end{tabular}

Table II shows current density that was calculated from the voltage and the resistor under each condition. Current density of the cases using activated carbon sheet was higher than the cases using carbon sheet. Furthermore, $0.6 \mathrm{~mm}$ thickness was better than $0.2 \mathrm{~mm}$ thickness. Because $0.6 \mathrm{~mm}$ thickness electrode has larger surface area than $0.2 \mathrm{~mm}$ electrode. Moreover, large surface area contribute to building good quality biofilm and low internal resistance. Similarly, using malt powder is better than using glucose in most cases. In particular, when $0.6 \mathrm{~mm}$ thickness activated carbon sheet is used, the difference between result of using malt powder and glucose is significant. In addition, current density of $220 \mu \mathrm{A} / \mathrm{cm}^{2}$ was the highest in our experiments when the conditions were $0.6 \mathrm{~mm}$ thickness activated carbon cultured using malt powder and connected to $1 \mathrm{k} \Omega$ external resistor.

\section{CONCLUSION}

In this study, anode material, anode thickness and culture medium were investigated. When carbon sheet was used as the electrodes, OCV was higher than using activated carbon sheet. However, the voltage over external resisters was lower than using activated carbon sheet, due to the high internal resistance of carbon sheet. Activated carbon sheet has larger surface area, which leads to its lower internal resistance. When $0.6 \mathrm{~mm}$ thickness substrate was used, it took about 10days to sufficiently build biofilm. Moreover, using $0.6 \mathrm{~mm}$ thickness activated carbon sheet was better than $0.6 \mathrm{~mm}$ carbon sheet. Finally, hydrophobic malt powder contributed to higher voltage output than using glucose. Especially, when $0.6 \mathrm{~mm}$ thickness activated carbon sheet and malt powder were used, the voltage was higher than other conditions. Using carbon sheet as electrode led to low current density due to its high internal resistance. On the other hands, using activated carbon sheet contributed to high current density. Therefore, using the combination of $0.6 \mathrm{~mm}$ thickness activated carbon sheet and malt powder led to an improvement of the MFC's performance.

\section{REFERENCES}

[1] D. Khater, K. M. El-khatib, and M. Hazaa, "Electricity generation using Glucose as substrate in microbial fuel cell," Journal of Basic and Environmental Sciences, vol. 2, pp. 84-98, 2015.

[2] A. Kouzuma, K. Hashimoto, and K. Watanabe, "Extracellular electron transfer mechanisms of shewanella oneidensis that facilitate current generation in microbial fuel cells," Journal of Environmental Biotechnology, vol. 9, no. 2, pp. 105-108, 2009

[3] S. Fatemi, A. A. Ghoreyshi, and G. Najafpour, "Bioelectricity generation in mediator-less microbial fuel cell: Application of pure and mixed cultures," Iranica Journal of Energy \& Environment, vol. 3, no. 2, 2012.

[4] C. J. Sund, M. M. Sun, and S. R. Crittenden, "Effect of electron mediators on current generation and fermentation in a microbial fuel cell," Appl. Microbiol. \& Biotechnol., vol. 76, no. 3, pp. 561-568, Sep. 2007.

[5] A. Vijay, T Kinra, and Y. K. Vijay, "Electricity generation from mediator-less MFC with consortia of carbon-zinc electrodes and CNT doped PEM," Helix, vol. 1, pp. 501-504, 2004.

[6] M. Schechter, A. Schechter, and S. Rozenfeld, Anode Biofilm, NC: INTECH, 2014, pp. 57-75.

[7] R. M. Donlan, "Biofilms: Microbial life on surfaces," Emerging Infectious Diseases, vol. 8, no. 9, pp. 881-890, September 2002.

[8] D. Kanatiwela, "Biofilms- a friend or foe?" Young Researchers" Forum- PGIS, 2014.

[9] L. Cernohorská and M. Votava, "Biofilms and their significance in medical microbiology," Epidemiol Mikrobiol Imunol., vol. 51, no. 4, pp. 161-164, 2002.

[10] J. Wu, "Modeling adsorption of organic compounds on activated carbon," Sweden by Solfjädern Offset AB, Umeå 2004.

[11] U. Karra, S. S. Manickam, and J. R. McCutcheon, "Power generation and organics removal from wastewater using activated carbon nanofiber (ACNF) microbial fuel cells (MFCs)," International Journal of Hydrogen Energy, vol. 38, no. 3, pp. 1588-1597, 2013.

[12] R. Rossi, A. Fedrigucci, and L. Setti, "Characterization of electron mediated microbial fuel cell by saccharomyces cerevisiae," Chemical Engineering Transactions, vol. 43, 2015.

[13] S. Iwai, T. Kikuchi, and T. Miura, "Simple culturing methods for yeast and teaching experiments," Bull. Fac. Educ. Hirosaki Univ., vol. 110, pp. 23-29, Oct. 2013.

[14] T. Jafry, A. A. Ghoreyshi, and G. D. Najafpour, "The effect of substrate concentration on the electrical performance of microbial fuel cell (MFC)," presented at the International Conference on Environment 2010.

[15] Y. Gao and S. Choi, "Stepping toward self-powered papertronics: Integrating biobatteries into a single sheet of paper," Advanced Materials Technologies, vol. 2, 2017

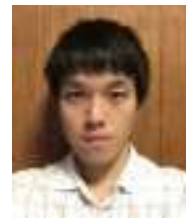

Naoki Hayashi was born in Okayama, Japan on July 7, 1993. He received his bachelor's degree in Department of Science and Engineering from Ritsumeikan University, Shiga, Japan in March 2017 and was admitted to a postgraduate course at same University on April 2017. He also belongs to an electronic system course of Department of Science and Engineering. He is now in the first year. He is making a study of microbial fuel cell that use E. coil as microbe in the graduate course.

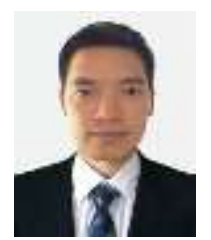

D. Trang Nguyen was born in Vietnam in 1986. He received the BS degree in 2009 from the Department of Telecommunication Systems Hanoi University of Science and Technology, Hanoi, Vietnam. After that he received the ME in 2011 from the Department of Electronics and Electrical Engineering, Dongguk University, Seoul, South Korea. From 2011 to 2014, he completed his Ph.D program in integrated science and engineering at Ritsumeikan University, Kyoto, Japan. After earning his Ph.D, he was a quality assurance engineer at Takako Industries, Inc. from 2015 to 2017. Currently, he is a postdoctoral researcher at the Ritsumeikan 
Global Innovation Research Organization, Ritsumeikan University. His fields of interest include biofuel cells, solar cells, biosensors and hydrogen energy.

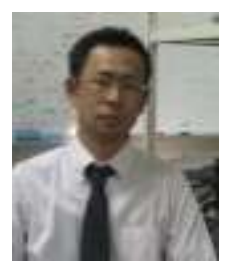

Kozo Taguchi was born in Kyoto, Japan, on December 18, 1968. He received the B.E., M.E., and

Dr. Eng. Degrees in electrical engineering from Ritsumeikan University, Kyoto, Japan, in 1991, 1993 and 1996, respectively. In 1996, he joined Fukuyama University, Hiroshima, Japan, where he had been engaged in research and development on the optical fiber trapping system, semiconductor ring lasers and their application for optoelectronics devices, and polymeric optical waveguides for optical interconnection. In 1996-2003, he worked as an assistant and lecturer in Fukuyama University. In 2003, he moved to Ritsumeikan University, Shiga, Japan, and currently he is a professor of Department of Electric and Electronic Engineering. From 2006 to 2007, he was a visiting professor at University of St Andrews (Scotland, United Kingdom). From 2014 to 2015, he was a visiting professor at Nanyang Technological University (Singapore). His current research interests include cells trap, microfluidic cell based devices, dye sensitized solar cell, biofuel cells. Dr. Taguchi is a member of the JJAP 